\title{
A COMPARATIVE STUDY ON CREATING A HEALTHY WORK ENVIRONMENT AND HR INITIATIVES WITH REFERENCE TWO LARGE SCALE INDUSTRIAL UNITS OF VISAKHAPATNAM
}

\author{
${ }^{1}$ Dr. Shaik Shamshuddin \\ ${ }^{1}$ Assistant Professor, \\ GITAM Institute of Management, \\ GITAM Deemed to be University.
}

\author{
${ }^{2}$ Dr. Shaik Haniefuddin \\ ${ }^{2}$ Professor in Management, \\ SIMS, \\ Visakhapatnam
}

\author{
${ }^{3}$ Dr. Shaik Khadar Baba \\ ${ }^{3} \mathrm{PA}$ to Principal, \\ Department of Arts and Commerce, \\ Andhra University,
}

Article DOI: https://doi.org/10.36713/epra2126

\begin{abstract}
This culture enables all employees to use their initiative, take risk, experiments, innovate and un-grade their potentialities to meet the existing and future challenges in short and long term perspectives. In this connection working conditions of employees within organization play a vital role for enhancing the economic productivity of an organization. At the national level, the dimension of HRD needs to be reviewed periodically and adjustments made according to the change in environment. India has one of the largest reservoirs of human resource in the World, which can combat any problem in the process of development especially at the economic level. The main objective of the study is to assess the levels of the utilization of human resources as well as to determine the functional status of the units. Keeping the above aspects under consideration, the study selected two large scale industrial units Viz., Hindustan Petroleum Corporation Ltd. and Coromandel Fertilizers Ltd. For the purpose of the study the data was collected from primary and secondary sources. Primary data was entered using SPSS (Statistical Package for Social Sciences) software and STATISTICA. Univariate and bi-variate tables were generated and chi-square tests and t-tests were carried out for testing the hypothesis at problem the level itself. The very purpose of this research is to know the opinion of the Employees on working conditions in Petrochemical and Fertilizer industries the effect of the development in industrial organizations and the development of productivity culture in the employees.
\end{abstract}

\section{INTRODUCTION}

In management, the concept of HRD was formally introduced in 1969 by Prof. Len Nadler in America at American society for Training and Development Conference. The concept of HRD has its relevance at both the micro and the macro levels in the context of improving the quality of human life. At the organizational level it is considered to be concerned with improving the quality of workers so as to achieve the higher levels of productivity. HRD was described as the core of all developmental efforts in view of improving the quality of the life of all human beings. The purpose of all developmental activities in a nation remains to improve the living conditions of the human beings.
Similarly, HRD at micro-level involves certain mechanisms and techniques such as performance of appraisal, counselling, training organizational development etc., to facilitate the development of human resources.

\section{NEED FOR THE STUDY}

Keeping the above aspects under consideration, the study assessed the levels of the utilization in human resources in the varied conditions particularly in the Petro-Chemical and Fertilizer industries which have become core industrial category in the existing and future scenario. The importance of human capital in any organization is increasing day by day. Apart from this the retention of talented people has become the biggest problem of 
the HR Manager. To involve workers at the grass root level for periodically discussing work related problems. Quality circle consists of small groups of employees which are formed voluntarily. They work on the simple premise that the people who do a job every day know more about it than anyone else, particularly when quality or productivity is involved.

\section{SCOPE OF THE STUDY}

The mechanism emphasizes the development of the employees (by identifying their growth needs) rather than their evaluation. Open, objective and participative appraisal and feedback develop better superior - subordinate relations. During the appraisal interview the superior shares the concerns of the subordinate and even guides him to achieve his targets. For overall development of workers, good wages alone are not enough. They also need to be provided with good physical conditions and amenities and motivating work.

\section{OBJECTIVES OF THE STUDY}

- To assess the status of working conditions of the employees in the selected units.

- To assess the role of human resource in the industry and also determine the encouragement on creativity and innovation status in selected Organizations.

- To trace the technological advancement related problems, bottlenecks and deficiencies arising in various spheres.

- To access the status of skill development and issues involved to sort out in selected organisations.

$$
(\mathrm{O}-\mathrm{E})^{2}
$$

\section{RESEARCH METHODOLOGY}

The research paradigms to be engaged in are dictated by the nature of the method, not by the preferred inquiry methodology of the researchertheorist or the practitioner-theorist (Lynham, 2002). The main objective of the study is to assess the levels of the utilization of human resources as well as to determine the functional status of the units. Keeping the above aspects under consideration, the study selected two large scale industrial units Viz., Hindustan Petroleum Corporation Ltd. and Coromandel Fertilizers Ltd. The survey is an important type of study it must not be confused with the more clerical routine of gathering and tabulating figures. It involves a clearly defined problem and definite objectives. It requires expert and imaginative planning, careful analysis and interpretation of the data gathered, logical and skillful reporting of the findings. Primary data was entered using SPSS (Statistical Package for Social Sciences) software and STATISTICA. Uni-variate and bi-variate tables were generated and chi-square tests and t-tests were carried out for testing the hypothesis at problem the level itself.

The $\chi^{2}$ test:

The Chi-square $\left(\chi^{2}\right)$ test is one of the simplest and most widely used non-parametric tests in statistical work. The symbol $\chi^{2}$ is the Greek letter chi. the $\chi^{2}$ test was first used by Karl Pearson in the year 1900. The quantity $\chi^{2}$ describes the magnitude of the discrepancy between theory and observation.

It is defined as: $\chi^{2}=\Sigma$

\section{E}

Where $\mathrm{O}$ refers to the observed frequencies and $\mathrm{E}$ refers to expected frequencies.

The t-test:

The t-distribution is an important statistical tool as number of variables taken in HPCL/CFL. The following are some of them;

1. T-test for significance for single means, population variables being unknown.

2. T-test for the significance of the difference between two sample means, the population variance being equal but unknown.

3. T-test for significance of an observed sample correlation coefficient

In this analysis the investigator has used the $\mathrm{t}$-test for testing the significance of the difference between two sample means. 
EPRA International Journal of Multidisciplinary Research (IJMR) - Peer Reviewed Journal Volume: 6 | Issue: 1 | January 2020 || Journal DOI: 10.36713/epra2013 || SJIF Impact Factor: 5.614||ISI Value: 1.188

The formulae used for this test is

$$
\mathrm{X}-\mathrm{Y} \sim \mathrm{tn}_{1}+\mathrm{n}_{2}-2
$$

$\mathrm{T}=$

$\mathrm{S} X \sqrt{ } \underline{1}+\underline{1}$

$\begin{array}{lll}\mathrm{n}_{1} & \mathrm{n}_{2}\end{array}$

Where $\mathrm{X}=\underline{1} \Sigma \mathrm{X}, \quad \mathrm{Y}=\underline{1} \Sigma \mathrm{Y}$

$\mathrm{n}_{1}$

$\mathrm{n}_{2}$

1

$\left[\Sigma(\mathrm{X}-\mathrm{X})^{2}+\Sigma(\mathrm{Y}-\mathrm{Y})^{2}\right]$

And $\mathrm{S}^{2}=$

$$
\mathrm{n}_{1}+\mathrm{n}_{2}-2
$$

\section{Sample of the Study}

The size of the sample is 200 employees from HPCL and 200 employees from CFL. The details of the distribution of the sample employees by their individual specifications and qualities are presented in the following tables. The sample distribution of the employees from the above two organizations mentioned above into different groups by their socio-economic variables presented the following components which was taken as criteria and tabulated as follows.

The following independent variables were studied for employees.

$\begin{array}{ll}\text { 1) } & \text { Gender } \\ \text { 2) } & \text { Age } \\ \text { 3) } & \text { Qualification } \\ \text { 4) } & \text { Designation } \\ \text { 5) } & \text { Department } \\ \text { 6) } & \text { Experience } \\ \text { 7) } & \text { Income }\end{array}$

\section{REVIEW OF LITERATURE}

An attempt is made in this chapter to review the earlier studies and research work, pertaining to human resource development, such a review is important since it indicates the responsiveness as well as helps in identifying the gaps in the existing literature.

\section{DATA ANALYSIS AND INTERPRETATION}

While national studies point to certain characteristics of a healthy working environment (time, resources, empowerment, management, leadership etc.), each industry and organization is unique. The employers need to ask employees what is important to them and what areas of the working environment need improvement. By asking employees, the industrial organizers can focus reforms on the area of greatest need. The view of the employees from HPCL \& CFL on working environment at the organization level is given in the following tables. 
ISSN (Online): 2455-3662

EPRA International Journal of Multidisciplinary Research (IJMR) - Peer Reviewed Journal Volume: 6 | Issue: 1 | January 2020 || Journal DOI: 10.36713/epra2013 || SJIF Impact Factor: 5.614||ISI Value: 1.188

\section{Facilities at Working Place in Organisation:}

\begin{tabular}{|c|c|c|c|c|c|c|c|}
\hline Industry & $\begin{array}{c}\text { Not at all } \\
\text { true }\end{array}$ & $\begin{array}{c}\text { Rarely } \\
\text { True }\end{array}$ & $\begin{array}{c}\text { Sometimes } \\
\text { True }\end{array}$ & $\begin{array}{c}\text { Mostly } \\
\text { True }\end{array}$ & $\begin{array}{c}\text { Almost } \\
\text { always True }\end{array}$ & Total & $\begin{array}{c}\text { Chi-square } \\
\text { value }\end{array}$ \\
\hline \multirow{2}{*}{ Hindustan Petroleum Co. Ltd. } & 34 & 29 & 55 & 51 & 31 & 200 & \multirow{6}{*}{$18.31^{* *}$} \\
\hline & $(17.0)$ & $(14.5)$ & $(27.5)$ & $(25.5)$ & $(15.5)$ & $(100.0)$ & \\
\hline \multirow{2}{*}{ Coromandel Fertilizers } & 31 & 12 & 79 & 63 & 15 & 200 & \\
\hline & (15.5) & $(6.0)$ & (39.5) & $(31.5)$ & (7.5) & (100.0) & \\
\hline \multirow{2}{*}{ Total } & 65 & 41 & 134 & 114 & 46 & 400 & \\
\hline & $(16.3)$ & $(10.3)$ & $(33.5)$ & $(28.5)$ & $(11.5)$ & $(100.0)$ & \\
\hline
\end{tabular}

Figure-17: Required facilities are available at w ork place

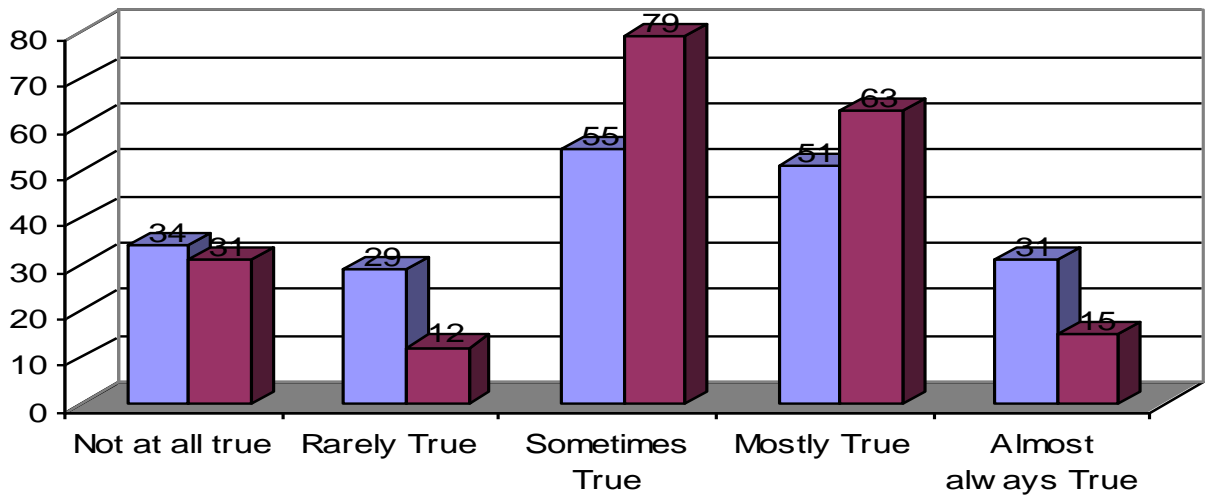

$\square$ Hindustan Petrolium Co.Ltd. $\square$ Coromandal Fertilizers

The generated chi-square value of 18.31 is significant at 0.01 level. This shows that there is a significant difference between the employees from the above two

Working Conditions

\begin{tabular}{|c|c|c|c|c|c|c|c|}
\hline Industry & $\begin{array}{c}\text { Not at all } \\
\text { true }\end{array}$ & $\begin{array}{c}\text { Rarely } \\
\text { True }\end{array}$ & $\begin{array}{c}\text { Sometimes } \\
\text { True }\end{array}$ & $\begin{array}{l}\text { Mostly } \\
\text { True }\end{array}$ & $\begin{array}{c}\text { Almost } \\
\text { always True }\end{array}$ & Total & $\begin{array}{c}\text { Chi-square } \\
\text { value }\end{array}$ \\
\hline Hindustan Petroleum Co. Ltd. & $\begin{array}{l}13 \\
(6.5)\end{array}$ & $\begin{array}{l}44 \\
(22.0)\end{array}$ & $\begin{array}{l}64 \\
(32.0) \\
\end{array}$ & $\begin{array}{l}49 \\
(24.5)\end{array}$ & $\begin{array}{l}30 \\
(15.0)\end{array}$ & $\begin{array}{l}200 \\
(100.0) \\
\end{array}$ & \multirow{3}{*}{$42.77^{* *}$} \\
\hline Coromandel Fertilizers & $\begin{array}{l}20 \\
(10.0)\end{array}$ & $\begin{array}{l}80 \\
(40.0)\end{array}$ & $\begin{array}{l}58 \\
(29.0)\end{array}$ & $\begin{array}{l}42 \\
(21.0)\end{array}$ & - & $\begin{array}{l}200 \\
(100.0)\end{array}$ & \\
\hline Total & $\begin{array}{l}33 \\
(8.3)\end{array}$ & $\begin{array}{l}124 \\
(31.0)\end{array}$ & $\begin{array}{l}122 \\
(30.5)\end{array}$ & $\begin{array}{l}91 \\
(22.8)\end{array}$ & $\begin{array}{l}30 \\
(7.5)\end{array}$ & $\begin{array}{l}400 \\
(100.0)\end{array}$ & \\
\hline
\end{tabular}

industries regarding the availability of required facilities at the work place. 
EPRA International Journal of Multidisciplinary Research (IJMR) - Peer Reviewed Journal Volume: 6 | Issue: 1 | January 2020 || Journal DOI: 10.36713/epra2013 || SJIF Impact Factor: 5.614||ISI Value: 1.188

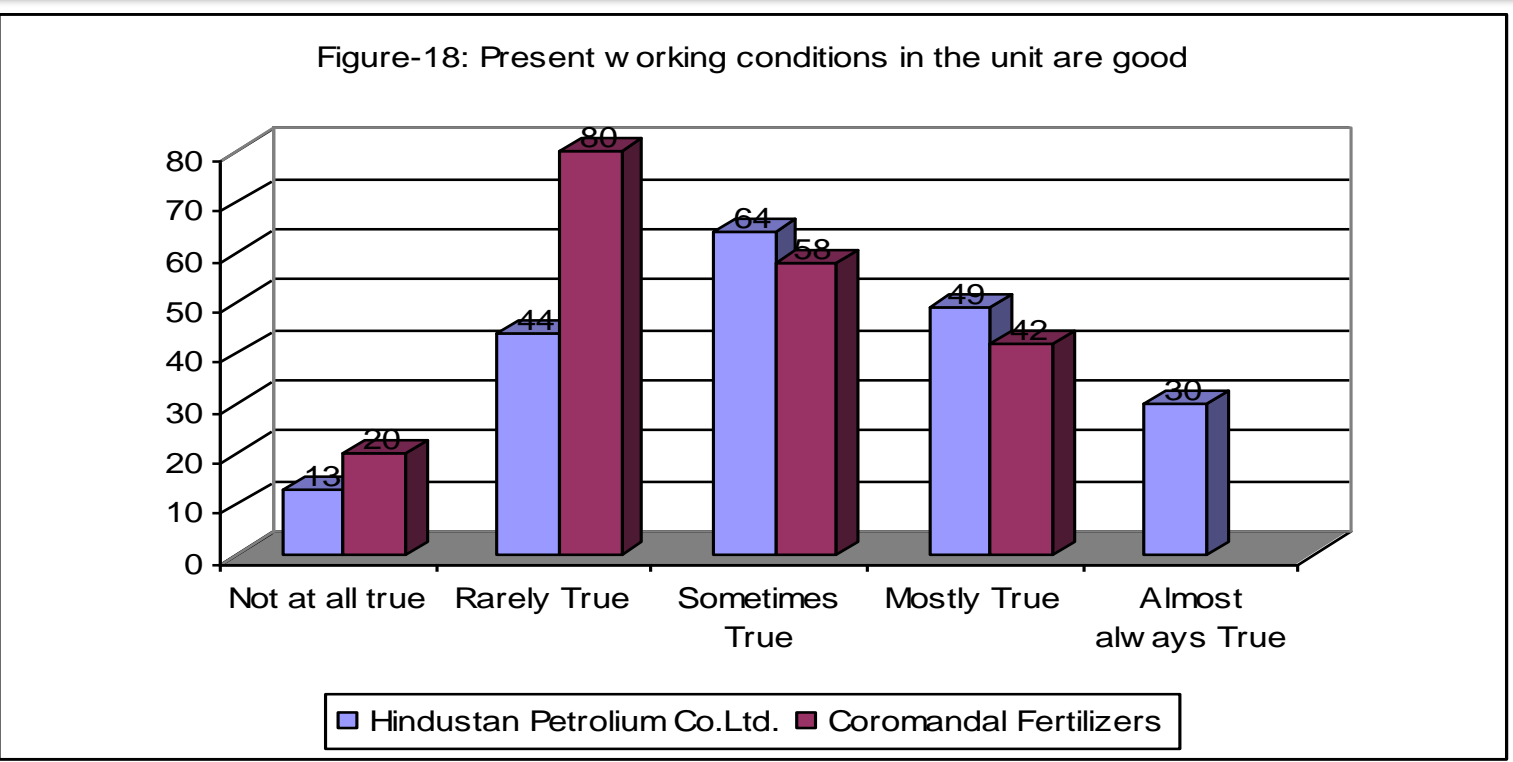

The calculated chi-square value is 42.77 is significant at 0.01 level. This shows that there is a significant difference in the opinions regarding the employees working in the above two industries on the statement 'Present working conditions in the unit is good.

Encouragement of creativity and innovation

\begin{tabular}{|l|l|l|l|l|l|l|l|}
\hline Industry & $\begin{array}{l}\text { Not at all } \\
\text { true }\end{array}$ & $\begin{array}{l}\text { Rarely } \\
\text { True }\end{array}$ & $\begin{array}{l}\text { Sometimes } \\
\text { True }\end{array}$ & $\begin{array}{l}\text { Mostly } \\
\text { True }\end{array}$ & $\begin{array}{l}\text { Almost } \\
\text { always True }\end{array}$ & Total & $\begin{array}{l}\text { Chi-square } \\
\text { value }\end{array}$ \\
\hline Hindustan Petroleum Co. Ltd. & 8 & 14 & 45 & 91 & 42 & 200 & \\
& $(4.0)$ & $(7.0)$ & $(22.5)$ & $(45.5)$ & $(21.0)$ & $(100.0)$ \\
\hline \multirow{2}{*}{ Coromandel Fertilizers } & 11 & 33 & 44 & 81 & 31 & 200 & \multirow{2}{*}{$10.40^{*}$} \\
& $(5.5)$ & $(16.5)$ & $(22.0)$ & $(40.5)$ & $(15.5)$ & $(100.0)$ & \\
Total & $\mathbf{1 9}$ & $\mathbf{4 7}$ & $\mathbf{8 9}$ & $\mathbf{1 7 2}$ & $\mathbf{7 3}$ & $\mathbf{4 0 0}$ & \\
& $\mathbf{( 4 . 8 )}$ & $\mathbf{( 1 1 . 8 )}$ & $\mathbf{( 2 2 . 3 )}$ & $\mathbf{( 4 3 . 0 )}$ & $\mathbf{( 1 8 . 3 )}$ & $\mathbf{( 1 0 0 . 0 )}$ & \\
\hline
\end{tabular}

Figure-24: Employees are encouraged to experiment with new methods and try out creative ideas

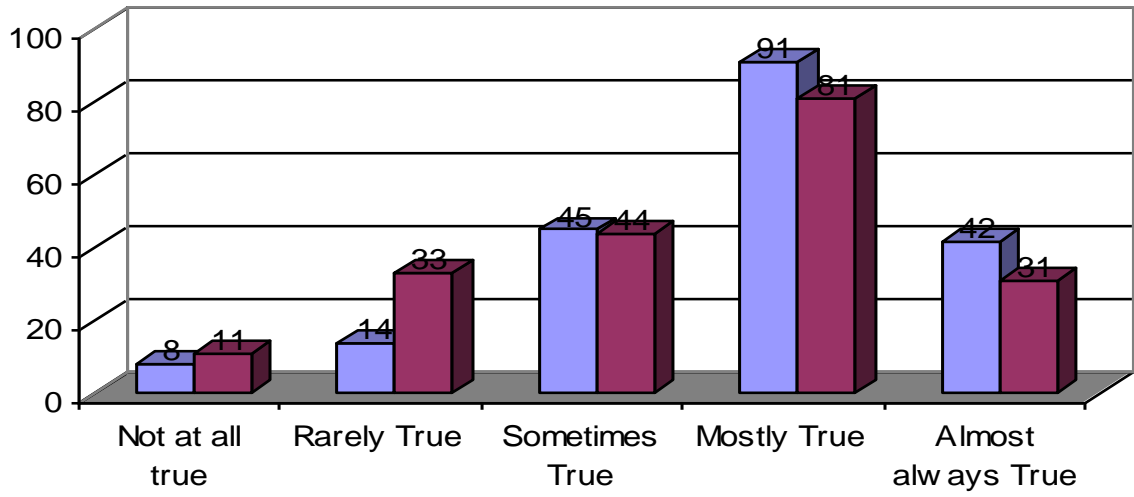

$\square$ Hindustan Petrolium Co.Ltd. $\square$ Coromandal Fertilizers 
The calculated chi-square value of 10.40 is significant at 0.05 level. This shows that there is a significant difference between the opinions of the employees working in the above two industries on the Skill development of Employees in Organisation statement 'employees are encouraged to experiment with new methods and try out creative ideas '. The symbolic representation is shown below.

\begin{tabular}{|c|c|c|c|c|c|c|c|}
\hline Industry & $\begin{array}{l}\text { Not at all } \\
\text { true }\end{array}$ & $\begin{array}{l}\text { Rarely } \\
\text { True }\end{array}$ & $\begin{array}{l}\text { Sometimes } \\
\text { True }\end{array}$ & $\begin{array}{l}\text { Mostly } \\
\text { True }\end{array}$ & $\begin{array}{l}\text { Almost } \\
\text { always True }\end{array}$ & Total & $\begin{array}{l}\text { Chi- } \\
\text { square } \\
\text { value }\end{array}$ \\
\hline Hindustan Petroleum Co. Ltd. & $\begin{array}{l}36 \\
(18.0)\end{array}$ & $\begin{array}{l}38 \\
(19.0)\end{array}$ & $\begin{array}{l}70 \\
(35.0)\end{array}$ & $\begin{array}{l}47 \\
(23.5)\end{array}$ & $\begin{array}{l}9 \\
(4.5)\end{array}$ & $\begin{array}{l}200 \\
(100.0)\end{array}$ & \multirow{3}{*}{7.50} \\
\hline Coromandel Fertilizers & $\begin{array}{l}40 \\
(20.0)\end{array}$ & $\begin{array}{l}19 \\
(9.5)\end{array}$ & $\begin{array}{l}80 \\
(40.0)\end{array}$ & $\begin{array}{l}50 \\
(25.0)\end{array}$ & $\begin{array}{l}11 \\
(5.5)\end{array}$ & $\begin{array}{l}200 \\
(100.0)\end{array}$ & \\
\hline Total & $\begin{array}{l}76 \\
(19.0)\end{array}$ & $\begin{array}{l}57 \\
(14.3)\end{array}$ & $\begin{array}{l}150 \\
(37.5)\end{array}$ & $\begin{array}{l}97 \\
(24.3)\end{array}$ & $\begin{array}{l}20 \\
(5.0)\end{array}$ & $\begin{array}{l}400 \\
(100.0)\end{array}$ & \\
\hline
\end{tabular}

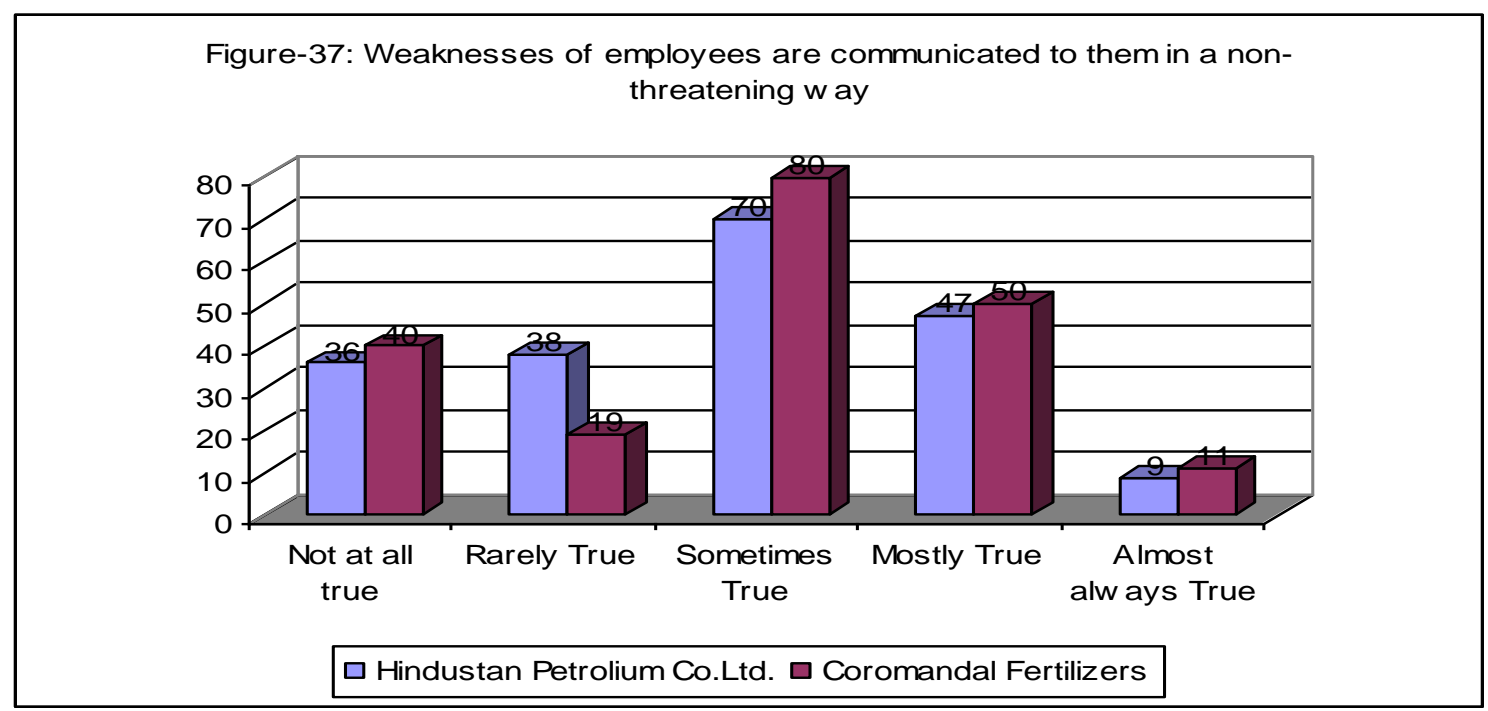

The generated chi-square value of 7.50 is not significant. This shows that there is no significant difference between the employees from the above two industries regarding the statement 'weaknesses of

\begin{tabular}{|l|l|l|l|l|l|l|l|}
\hline Industry & $\begin{array}{l}\text { Not at all } \\
\text { true }\end{array}$ & $\begin{array}{l}\text { Rarely } \\
\text { True }\end{array}$ & $\begin{array}{l}\text { Sometimes } \\
\text { True }\end{array}$ & $\begin{array}{l}\text { Mostly } \\
\text { True }\end{array}$ & $\begin{array}{l}\text { Almost always } \\
\text { True }\end{array}$ & $\begin{array}{l}\text { Total } \\
\text { Chi-square } \\
\text { value }\end{array}$ \\
\hline Hindustan Petroleum Co. Ltd. & 27 & 34 & 59 & 51 & 29 & 200 \\
$(13.5)$ & $(17.0)$ & $(29.5)$ & $(25.5)$ & $(14.5)$ & $(100.0)$ \\
\hline Coromandel Fertilizers & 44 & 27 & 64 & 54 & 11 & 200 \\
$(100.0)$ & $13.26^{* *}$ \\
\hline Total & $(22.0)$ & $(13.5)$ & $(32.0)$ & $(27.0)$ & $(5.5)$ & \\
$(\mathbf{7 1}$ & $\mathbf{6 1}$ & $\mathbf{1 2 3}$ & $\mathbf{1 0 5}$ & $\mathbf{4 0}$ & $\begin{array}{l}\mathbf{4 0 0} \\
(\mathbf{1 0 0 . 0 )}\end{array}$ \\
\hline
\end{tabular}


EPRA International Journal of Multidisciplinary Research (IJMR) - Peer Reviewed Journal Volume: 6 | Issue: 1 | January 2020 || Journal DOI: 10.36713/epra2013 || SJIF Impact Factor: 5.614||ISI Value: 1.188

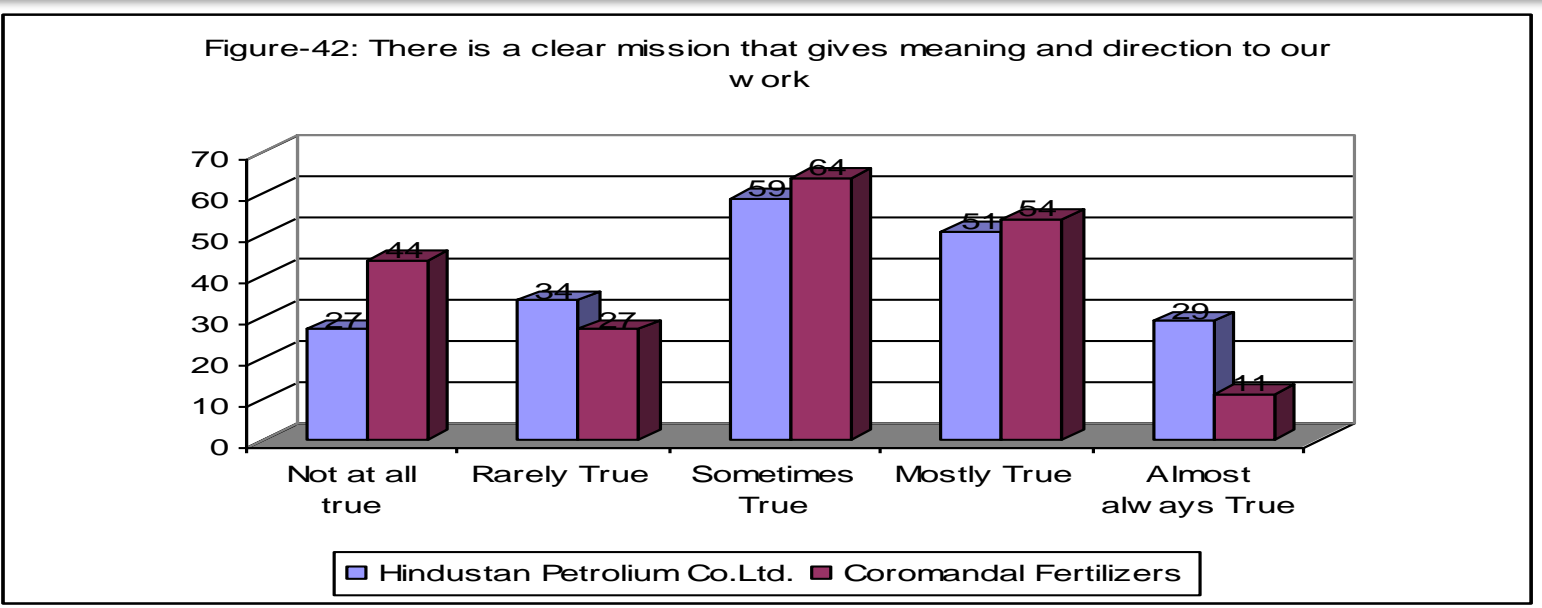

The generated chi-square value of 13.26 is significant at 0.01 level. This shows that there is a significant difference between the employees in the above two industries regarding the statement 'there is Clear Strategic vision a clear mission that gives meaning and direction to our work'. The graphic representation is shown below.

\begin{tabular}{|c|c|c|c|c|c|c|c|}
\hline Industry & $\begin{array}{c}\text { Not at all } \\
\text { true }\end{array}$ & $\begin{array}{c}\text { Rarely } \\
\text { True }\end{array}$ & $\begin{array}{c}\text { Sometimes } \\
\text { True }\end{array}$ & $\begin{array}{c}\text { Mostly } \\
\text { True }\end{array}$ & $\begin{array}{c}\text { Almost always } \\
\text { True } \\
\end{array}$ & Total & $\begin{array}{l}\text { Chi-square } \\
\text { value } \\
\end{array}$ \\
\hline Hindustan Petroleum Co. Ltd. & $\begin{array}{l}15 \\
(7.5)\end{array}$ & $\begin{array}{l}26 \\
(13.0)\end{array}$ & $\begin{array}{l}74 \\
(37.0)\end{array}$ & $\begin{array}{l}66 \\
(33.0)\end{array}$ & $\begin{array}{l}19 \\
(9.5)\end{array}$ & $\begin{array}{l}200 \\
(100.0)\end{array}$ & \multirow{3}{*}{7.53} \\
\hline Coromandel Fertilizers & $\begin{array}{l}31 \\
(15.5)\end{array}$ & $\begin{array}{l}18 \\
(9.0)\end{array}$ & $\begin{array}{l}75 \\
(37.5)\end{array}$ & $\begin{array}{l}59 \\
(29.5)\end{array}$ & $\begin{array}{l}17 \\
(8.5)\end{array}$ & $\begin{array}{l}200 \\
(100.0)\end{array}$ & \\
\hline Total & $\begin{array}{l}46 \\
(11.5)\end{array}$ & $\begin{array}{l}44 \\
(11.0)\end{array}$ & $\begin{array}{l}149 \\
(37.3)\end{array}$ & $\begin{array}{l}125 \\
(31.3)\end{array}$ & $\begin{array}{l}36 \\
(9.0)\end{array}$ & $\begin{array}{l}400 \\
(100.0)\end{array}$ & \\
\hline
\end{tabular}

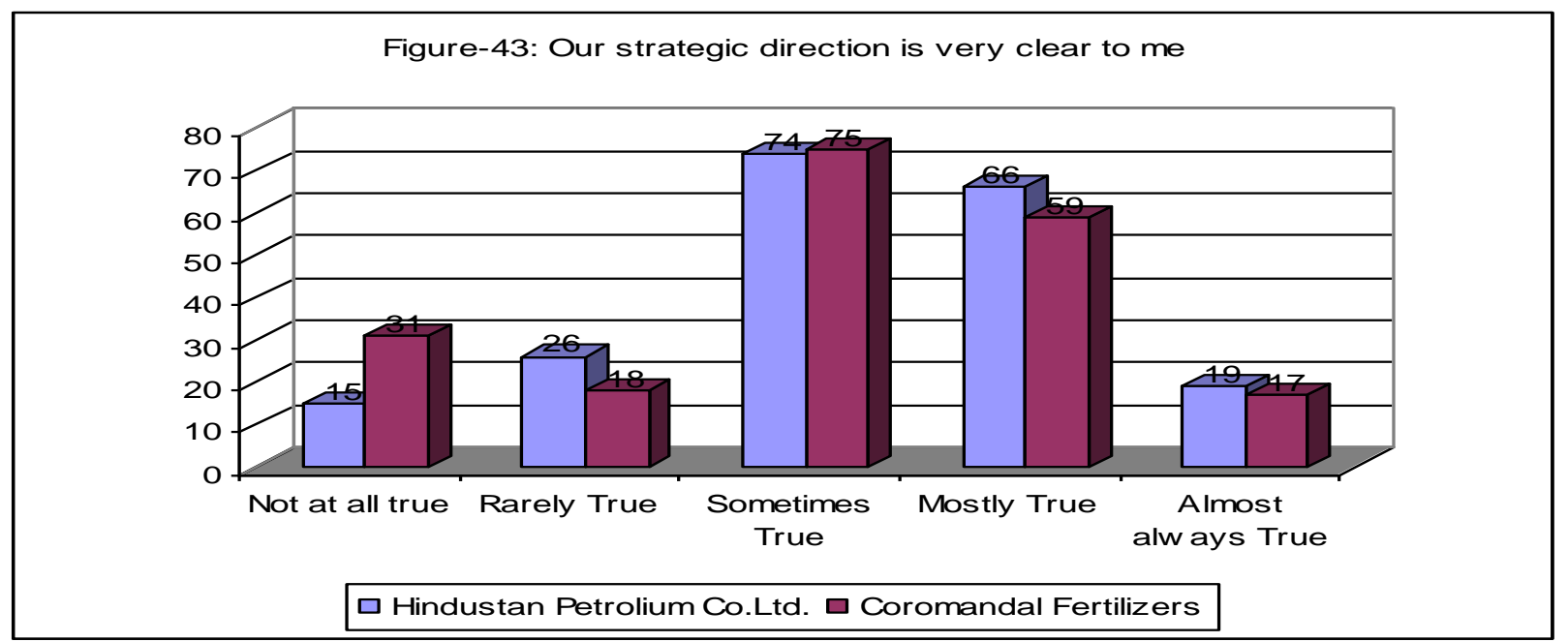

The generated chi-square value of 7.53 is not significant. This shows that there is no significant difference between the employees in the above two industries on the statement 'our strategic direction is very clear to me'. The symbolic representation is shown below. 
EPRA International Journal of Multidisciplinary Research (IJMR) - Peer Reviewed Journal Volume: 6 | Issue: 1 | January 2020 || Journal DOI: 10.36713/epra2013 || SJIF Impact Factor: 5.614||ISI Value: 1.188

\section{Continuous Track of Progress against Stated Goals}

\begin{tabular}{|l|l|l|l|l|l|l|l|}
\hline Industry & $\begin{array}{l}\text { Not at all } \\
\text { true }\end{array}$ & $\begin{array}{l}\text { Rarely } \\
\text { True }\end{array}$ & $\begin{array}{l}\text { Sometimes } \\
\text { True }\end{array}$ & $\begin{array}{l}\text { Mostly } \\
\text { True }\end{array}$ & $\begin{array}{l}\text { Almost always } \\
\text { True }\end{array}$ & $\begin{array}{l}\text { Total } \\
\text { value }\end{array}$ \\
\hline Hindustan Petroleum Co. Ltd. & $\begin{array}{l}28 \\
(14.0)\end{array}$ & $\begin{array}{l}39 \\
(19.5)\end{array}$ & $\begin{array}{l}72 \\
(36.0)\end{array}$ & $\begin{array}{l}52 \\
(26.0)\end{array}$ & $\begin{array}{l}9 \\
(4.5)\end{array}$ & 200 \\
$(100.0)$ & \\
\hline Coromandel Fertilizers & 5 & 84 & 40 & 68 & 3 & 200 \\
$(20.0)$ & $(34.0)$ & $(1.5)$ & $46.77^{* *}$ \\
\hline Total & $(2.5)$ & $(42.0)$ & $(100.0)$ & \\
& $\mathbf{3 3}$ & $\mathbf{1 2 3}$ & $\mathbf{1 1 2}$ & $\mathbf{1 2 0}$ & $\mathbf{1 2}$ & $\mathbf{4 0 0}$ \\
$\mathbf{( 8 . 3 )}$ & $\mathbf{( 3 0 . 8 )}$ & $\mathbf{( 2 8 . 0 )}$ & $\mathbf{( 3 0 . 0 )}$ & $\mathbf{( 3 . 0 )}$ & \\
\hline
\end{tabular}

The generated chi-square value of 46.77 is significant at 0.01 level. This shows that there is a significant difference between the employees in the above two industries regarding the statement "we continuously track our progress against our stated goals'. The Pictorial representation is shown below.

Figure-46: We continuously track our progress against our stated goals

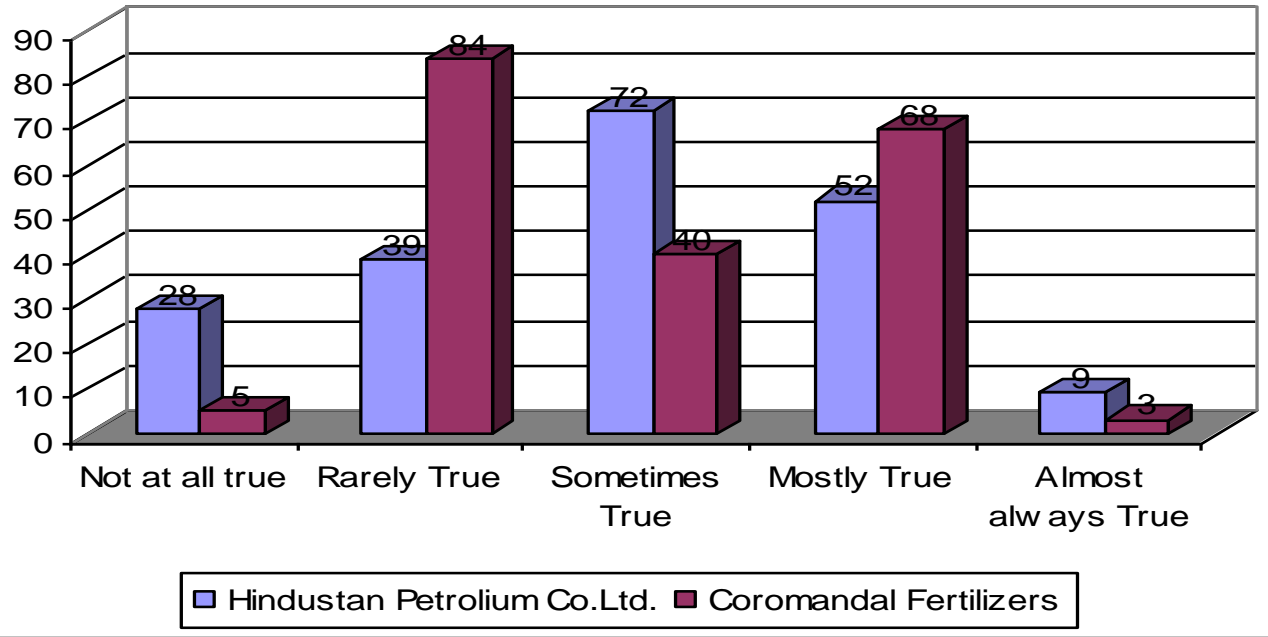

The Performance of Human Resources Development among the Employees in Selected Industries on Working Environment

\begin{tabular}{|l|l|l|l|l|l|}
\hline Industry & $\mathbf{N}$ & Mean & $\begin{array}{l}\text { Standard } \\
\text { Deviation }\end{array}$ & t-value & p-value \\
\cline { 1 - 4 } Hindustan Petroleum Co. Ltd. & 200 & 8.20 & 2.73 & 2.896 & 0.004 \\
\hline Coromandel Fertilizers & 200 & 7.33 & 3.22 & & \\
\hline Total & $\mathbf{4 0 0}$ & 7.76 & 3.01 & & \\
\hline
\end{tabular}

The perception of Working Environment conditions is stronger for employees of HPCL as compared to those of CFL. The mean values of HPCL and CFL industries are 8.20 and 7.33 respectively. The ' $t$ ' value 2.896 indicates that the difference is significant at 0.01 level. This shows that

there is a significant difference in the performance of the employees between the two industries on Working Environmental conditions in the industry. Hence the null hypothesis is rejected. The graphic representation is shown below. 
Figure-51: The performance of human resources development among the employees in selected industries on Working Environment

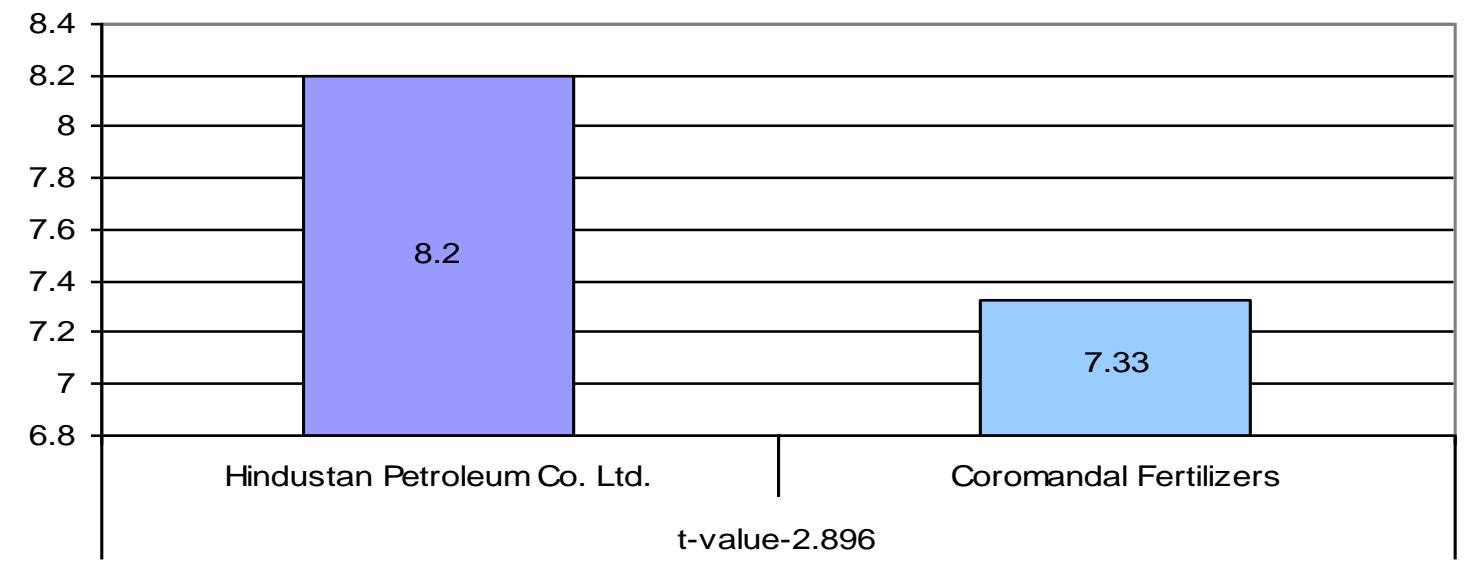

\section{Major Findings of the study:}

- Employees of the two compares felt differently when asked regarding the availability of required facilities at work place.

- There is a significant difference in the opinions of the employees working in the two industries for present working conditions in the unit is good.

- There is a significant difference in the opinions of the employees working in the two industries on employees returning from training programs are given opportunities to try out what they have learned.

- There is a significant difference in the opinion of the employees between the two industries regarding the employees are encouraged to experiment with new methods and try out creative ideas .

- There is a significant difference between the employees from the above two industries about the top management of the organization goes out of its way to make sure that the employees enjoy their work.

- The employees of HPCL are more significant performance than CFL regarding Working Environmental conditions in the industry.

\section{SUMMARY AND CONCLUSION}

Based on the research findings the organisation seems to possess this shared meaning and common perception regarding the HRD practices as measured by the Strategic Random Survey. HR Manager has to prepare small printed cards of the major HR Policies for effective involvement of employees in work of HPCL and CFL and distribute this to all the employees. It is also felt that there is a lot of resistance among the employees in both the organizations. If the employees are involved in the change process, there is a chance to reduce the resistance. At the same time the superior has to educate the employees before bringing any change in their work. This may improve the employees' satisfaction level. The employees will be more creative and innovative in their work which leads to high productivity. An attempt was made in this study to assess the levels of the utilization of the human resources as well as to the functional status of the human resources in the units. The study also traced out various problems, deficiencies and bottlenecks faced by the workers at grassroots levels. The main objective of the study is the existing status of the working conditions in the Petrochemical and Fertilizer Industries Sectors. Keeping the above aspects under consideration, an attempt is made in this study to analyze the extent of utilization of human resources in the selected units as well as to assess the working conditions in HPCL/CFL adopted. For this purpose the study collected wide information about the working conditions as well as the policy of the selected units. This study dealt with the assessment of the status of the role of the working conditions and human resource development of the selected units.

\section{REFERENCES}

1. Sharma, A and Purang, P., (2000), "Value Institutionalization and HRD Climate: A Case Study of a Navratna Public Sector Organisation", Vision-The Journal of Business Perspective, Vol. 4 , pp 11-17.

2. Kumar, Sharad and Patnaik P. Sabita (2002), "Human Resource Development Climate and Attributes of Teachers in JNVs", The Indian Journal of Training and Development, Vol.XXXII, No. 2.

3. Budhwar, P. and Boyne, G. (2004) 'Human Resource Management in the Indian Public and Private Sectors: An Empirical Comparison', the International Journal of Human Resource Management, 15(2): 346-70. 
4. Richard J. Torraco (2004) "Challenges and choices for theoretical research in human resource development", Human Resource Development Quarterly, Volume 15, Issue 2, Pages: 171-188.

5. Dr. S.Yuvaraj, (2005) "Effectiveness of Training ''ILTD Journal XXXV Vol 4.

6. Jyotsna Bhatnagar and Anuradha Sharma., (2005) "The Indian perspective of strategic $H R$ roles and organizational learning capability" Int. J. of Human Resource Management 16:9 September pp 1711-1739.

7. Srimannarayana M (2007), "Human Resource Development Climate in a Dubai Bank", Icfai Journal of Organizational Behavior, Vol. 6, No. 1, pp. 33-40.

8. Thomas J. Chermack and Richard A. Swanson (2008) "Scenario Planning: Human Resource Development's Strategic Learning Tool", Journal of Advances in Developing Human Resources, Vol. 10, No. 2, pp.129-146.

9. Claire Gubbins (2009) Understanding the HRD Role in MNCs:The Imperatives of Social Capital and Networking, Human Resource Development Review.

10. Chang-Wook Jeung, Sunyoung Park and Hea Jun Yoon (2009) "Who is citing whom: Citation network analysis among HRD publications from 1990 to 2007" Human Resource Development Quarterly, Volume 20, Issue 4, Pages: 503-537.

11. Yoshie Tomozumi Nakamura (2011) "The Role of Reflective Practices in Building Social Capital in Organizations from an HRD Perspective" Human Resource Development Review.

12. Moon K, Lee J, Oah S. The effects of safety leadership of manager and safety climate in the organization on the workers' safety behaviors. Journal of the Korean Society of Safety 2013; 28 (3): $\quad$ 66-72. Howell DC. Fundamental statistics for the behavioral sciences (8th ed.). Belmont (CA): Wadsworth CENGAGE Learning; 2014. p. 266.

13. Park KO. Organizational factors associated with safety and health managers' educational needs Korean Public Health Research 2016; 42 (1): 41-52.

14. Kim SB, Park JK. A study on the role of safety and health of supervisors in small to mediumsized industries. Journal of the Korean Society of Safety 2013; 28 (2): 84-87. 